\title{
MOVEMENT OF BANDED BATS IN ALBERTA*
}

HUGH C. SMITH, Provincial Museum of Alberta, Edmonton.

Movements of big brown bats Eptesicus fuscus and little brown bats Myotis lucifugus in western Canada are poorly known. As a result of a recent banding program, the movements of three individuals of these species deserves some mention.

A juvenile female big brown bat banded on 21 July 1977 at a nursery colony near Stony Plain, Alberta, was recovered on 26 November 1977 near Caroline, Alberta. The straight line distance between these two locations is approximately $176 \mathrm{~km}$ (104 mi.). This return is the first recapture in Alberta of a big brown bat away from the place of banding.

Big brown bats are considered sedentary species and long distance movements are uncommon. 1 Table 1 lists the distances moved by big brown bats that have been reported by various authors. It indicates that immatures of both sexes are involved in long distance movements.

One purpose of the banding program that was initiated in 1972 was to attempt to discover where our plains region bats were going in the winter and where the hibernating bats were spending the surnmer. Little brown bats are distributed throughout the plains region of Alberta during the summer. Their known winter distribution in the province is at three hibernacula wo in the mountains in southwestern Alberta and one in Wood Buffalo National Park in northern Alberta.

Natural History Contribution No. 52.
None of these hibernacula contain a population of bats large enough to account for the summer population of even a medium sized nursery colony. Unfortunately we have yet to document movements of bats between the mountains and plains regions. However, one bat has shown at least a tendency to move from the plains regions toward the mountains.

An adult male little brown bat banded on 8 September 1977 in Edmonton, Alberta was recovered on 13 September 1977 near Rocky Mountain House, Alberta; a movement in a southwest direction of approximately $150 \mathrm{~km}$ (90 mi.) in five days. Rocky

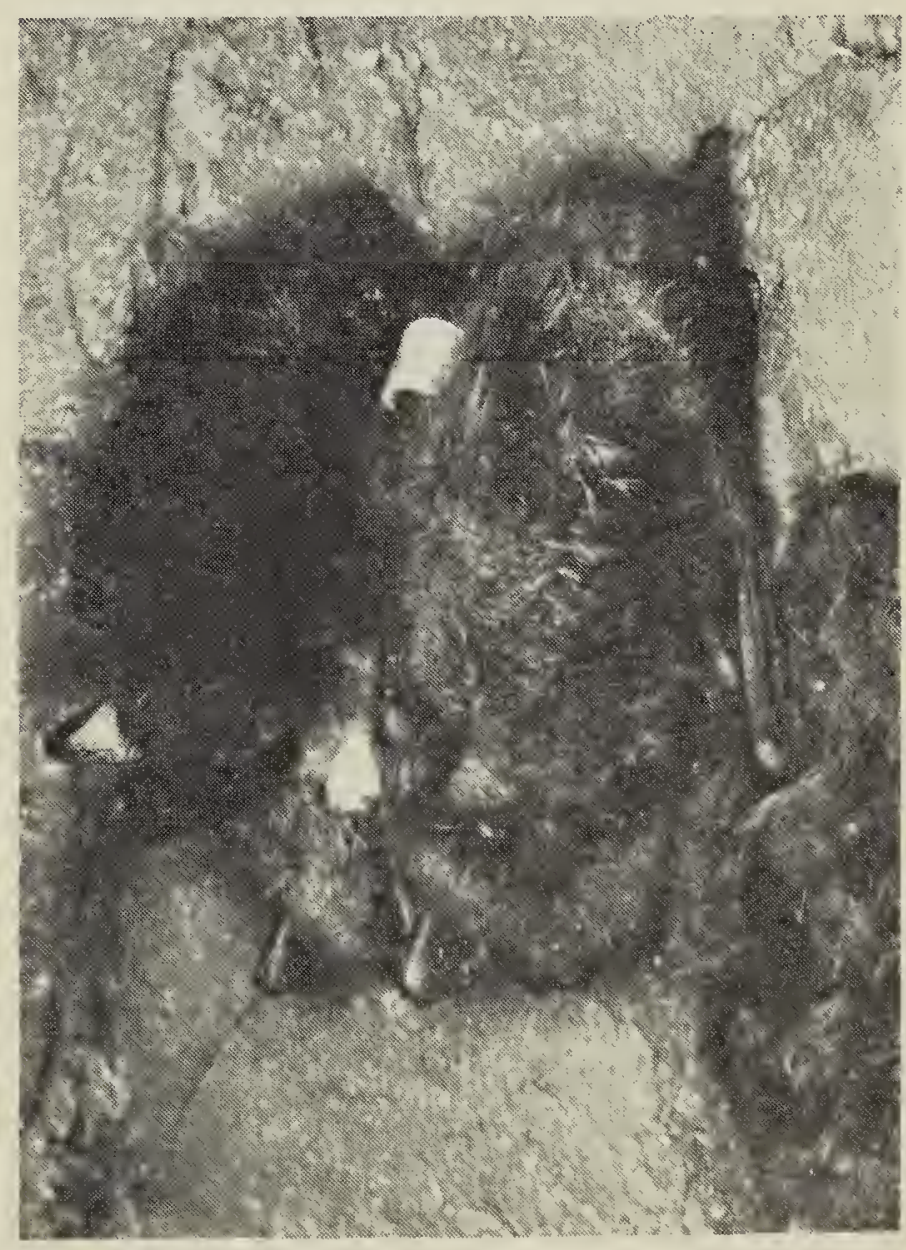

Banded little brown bats, Cadomin Cave, Alberta Lawrence Harder 
TABLE 1. Movement of big brown bats.

Author

Beer, $1955^{2}$

Mumford, $1958^{8}$

Brenner, $1968^{3}$

Davis, et. al., 19694

Goehring, $1972^{5}$

Mills, et. al., $1975^{7}$

Mills, et. al., $1975^{7}$

this study
Sex

M

$M$

$M$

$\mathrm{F}$

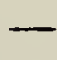

F

M

$\mathrm{F}$
Age

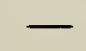

-

immature

Adult

immature

immature

immature
Distance

98 km (61 mi.)

227 km (142 mi.)

$32 \mathrm{~km}$ (20 mi.)

$55 \mathrm{~km}$ (32 mi.)

$88 \mathrm{~km}$ (55 mi.)

$280 \mathrm{~km}$ (180 mi.)

248 km (155 mi.)

176 km (104 mi.)
Mountain House is within $80 \mathrm{~km}$ (50 mi.) of the mountains.

A second little brown bat recovered west of its banding site was an adult female banded at a nursery colony near Bonnyville (east central Alberta) on 11 July 1972. This bat was recaptured at the same nursery colony on 4 June 1973. On 9 June 1974 it was killed at Onoway, Alberta, approximately $225 \mathrm{~km}$ (136 mi.) southwest of the banding site.

Although the distance travelled by either of these little brown bats is not remarkable both represent movement towards the mountains. 6 However, the date and lack of data on the circumstances of capture of the second bat limit the interpretation of this record.

The number of bats that have been banded in the province is relatively small, but several have come to the attention of members of the general public. The three movements described here all were as a result of a member of the general public taking the trouble to advise appropriate authorities of their finds. Without the co-operation of the public such programs as bat banding would be sorely limited with respect to obtaining results of bat movements away from areas of initial banding.
I would like to thank David Schowalter, of the Alberta Fish and Wildlife Division for his comments on this note and for the effort he has put forth in banding bats in Alberta.

1BARBOUR R. W. and W. H. DAVIS. 1969. Bats of America. Univ. Press of Kentucky, Lexington, Kentucky. 286 pp.

2BEER, J. R. 1955. Survival and movement of banded big brown bats. J. of Mammalogy 36:242-248.

3BRENNER, R. J. 1968. A three year study of two breeding colonies of the big brown bat, Eptesicus fuscus. J. Mammalogy 49:775-778.

${ }^{4}$ DAVIS, W. H., R. W. BARBOUR and M. D. HASSELL. 1968. Colonial behavior of Eptesicus fuscus. J. Mammalogy 49:44-50.

5GOEHRING, H. H. 1972. Twenty-year study of Eptesicus fuscus in Minnesota. J. Mammalogy 53:201-207.

6HUMPHREY, S. R. and J. B. COPE. 1976. Population ecology of the little brown bat, Myotis lucifugus, in Indiana and north-central Kentucky. Special Publ. No. 4 American Society of Mammalogists. 81 pp..

7 MILLS, R. S., G. W. BARRETT, and M. P. FARRELL. 1975. Population dynamics of the big brown bat (Eptesicus fuscus) in southwestern Ohio. J. Mammalogy 56:591-604.

8MUMFORD, R. E. 1958. Population turnover in wintering bats in Indiana. J. Mammalogy 39:253-261. 